\title{
Diversity and community assembly patterns of epigean vs. troglobiont spiders in the Iberian Peninsula
}

\author{
Pedro Cardoso ${ }^{1}$
}

\begin{abstract}
:
Cardoso P. 2012. Diversity and community assembly patterns of epigean vs. troglobiont spiders in the Iberian Peninsula. International Journal of Speleology, 41(1), 83-94. Tampa, FL (USA). ISSN 0392-6672. http://dx.doi.org/10.5038/1827-806X.41.1.9

Cave-obligate organisms usually have smaller ranges and their assemblages have higher beta diversity than their epigean counterparts. Phylogenetic and functional diversity is usually low in cave communities, leading to taxonomic and functional disharmony, with entire groups missing from the subterranean realm. The objective of this work is to compare range, beta diversity, phylogenetic and functional diversity, taxonomic and functional disharmony of epigean versus troglobiont spiders in the Iberian Peninsula. The median extent of occurrence was found to be 33 times higher for epigean than for cave species. Beta diversity was significantly higher for troglobiont assemblages. Cave assemblages present lower phylogenetic and functional diversities than expected by chance. Taxonomic disharmony was noticeable, with many speciose families, namely Gnaphosidae, Salticidae and Lycosidae, absent in caves. Functional disharmony was equally high, with ambush hunters and sensing web weavers being absent in caves. The small range and high beta diversity of troglobiont spiders in the Iberian Peninsula is typical of many cave-obligate organisms, caused by the fragmentation and isolation of cave systems and the low vagility and high habitat specialization of species. Caves were colonized mainly by pre-adapted lineages, with high proportions of eutroglophile species. Some families no longer occur in surface habitats, possibly since the last glaciations, and currently are restricted to caves in the region. Few hunting strategies and web types are efficient in caves and these dominate among the troglobiont species. As troglobiont communities are of low alpha diversity, with low functional redundancy, have narrow ranges, present high levels of population fragmentation and are taxonomically unique, they should present higher proportions of imperilled species than epigean spiders in the Iberian Peninsula. Some species are probably endangered and require urgent conservation measures.
\end{abstract}

Keywords: Araneae; Arthropoda; beta diversity; disharmony; extent of occurrence; functional diversity; phylogenetic diversity; range

Received 14 July 2011; Revised 21 October 2011; Accepted 20 December 2011

\section{INTRODUCTION}

Cave-obligate species richness is related with habitat availability, namely the number of caves (Christman \& Culver, 2001; Culver et al., 2003, 2004), but it is usually low compared with the richness of surface habitats for most taxa. Caves are usually restricted to certain geological areas, such as karstic regions and volcanic areas and these can be seen as islands surrounded by inhospitable habitat. Disjunction of cave systems and consequent reduced dispersal of organisms are important in determining that cave-obligate species usually exhibit narrower ranges and higher endemics proportions than their epigean counterparts (Barr \& Holsinger, 1985; Culver et al., 2000; Sharratt et al., 2000; Gibert \&

\footnotetext{
${ }^{1}$ Smithsonian Institution, National Museum of Natural History, Washington, DC, USA (pcardoso@ennor.org), Azorean Biodiversity Group - CITA-A, University of the Azores, Angra do Heroísmo, Portugal. Associação dos Espeleólogos de Sintra, Sintra, Portugal. Núcleo de Espeleologia da Costa Azul, Sesimbra, Portugal.
}

Deharveng, 2002; Christman et al., 2005; Borges et al., 2007; Ferreira et al., 2007; Michel et al., 2009). This pattern is more marked with troglobionts than stygobionts. The latter generally have larger ranges (Culver et al., 2000; Lamoreux, 2004) as subterranean aquatic habitats have higher connectivity than terrestrial habitats (Christman \& Culver, 2001). In any case, such patterns of low local richness, narrow distribution and high endemism in both troglobionts and stygobionts have been extensively documented (Culver \& Pipan, 2009).

Beta diversity patterns of cave-obligates have received much less attention (Malard et al., 2009). Beta diversity was first defined as the extent of change in community composition along gradients (Whittaker, 1960) and as an essential component for the understanding of overall diversity (Whittaker, $1960,1972)$. Since then, the term has been used to refer to a variety of phenomena, although all of these encompass some kind of compositional heterogeneity or differentiation between sites (Tuomisto, 2010a,b; Anderson et al., 2011). In general, it is expected that assemblages composed by that taxa with narrower 
ranges present higher beta diversity values between sites and this should hold for comparisons between epigean and cave assemblages in the same taxonomic group.

Caves are subject to strong environmental filters, as the lack of light and scarce energy input constitute a challenge to the adaptation of organisms. As a consequence, they constitute excellent systems to study community assembly patterns. The unique composition of cave communities may be a consequence of both phylogenetic clustering, as only some families or genera may have pre-adaptations to subterranean living, and functional clustering, as only some guilds may be able to live in such environment (Cavender-Bares et al., 2009; Pausas \& Verdú, 2010). On the other hand, competitive interactions may cause closely related species to be unable to co-exist and in such case the environmental filtering would not be reflected on community composition (see a review in Cavender-Bares et al., 2009). It is possible, however, that the importance of both mechanisms, environmental filtering and competitive interactions, is scale-dependent. On a small-scale, such as a single cave or karstic region, competitive interactions would be prevalent and co-existing species would be phylogenetically and functionally distant. On a large scale, such as a biogeographic region, related species could occupy different areas and the environmental filtering favouring certain clades or functional traits would be determinant.

Taxonomic disharmony is a term commonly used in island biogeography and defined as a different balance in taxonomic composition of a community in relation to a mainland (or larger island) source (Whittaker et al., 1997; Whittaker \& FernándezPalacios, 2007). Taxonomic disharmony has two interrelated causes. First, isolation, leading to the absence of many taxa (genera, families or even higher taxonomic levels) from islands, especially oceanic islands (Whittaker et al., 1997; Whittaker \& FernándezPalacios, 2007). Second, evolutionary distinctiveness, with some taxa diversifying in unusual ways (Gillespie $\&$ Roderick, 2002). Just as island faunas are often named "disharmonic", product of a filter that favours some taxa (e.g. with higher dispersal capacity), cave faunas may suffer the same effect, as some taxa (e.g. with certain morphological or physiological characteristics) may be favoured in the occupation of caves. Taxonomic disharmony in caves was already described for a number of taxa and regions (e.g. Gibert $\&$ Deharveng, 2002; Ferreira et al., 2007).

On isolated islands, the few species that are able to colonize them often occupy niches and perform ecosystem functions left vagrant by taxa that did not have the ability to reach and reproduce on the region (Gillespie \& Roderick, 2002). Therefore, taxonomic disharmony may not originate functional disharmony. Functional disharmony may be defined as a different balance in functional composition of a community in relation to the source. Because caves are a radically different environment to any surface habitat, many niches are completely absent. Consequently, entire guilds or functional groups, common on the surface, may be entirely absent in caves. Functional disharmony in caves may be as clear as taxonomic disharmony, due to the characteristics of the habitat. In fact, on a coarse level, if four main trophic groups are usually present on the surface (producers, herbivores, predators/parasites and decomposers), only two of these, predators/parasites and decomposers are common in caves (Mohr \& Poulson, 1966). With the exception of plant roots infiltrating the soil down to sub-superficial caves (Gibert \& Deharveng, 2002) or chemolithotrophic organisms (Kindle \& Kane, 2000; Northup \& Lavoie, 2001), primary producers are absent, as are herbivores, with the exception of rootfeeders (Howarth, 1983). Subterranean communities may therefore be considered as "disharmonic", with decomposers at the base of food chains (Gibert \& Deharveng, 2002).

With more than 42000 described species (Platnick, 2011), spiders constitute the seventh most diverse order worldwide. Despite their high diversity and ubiquity, many species have restricted distributions and biogeographic patterns of assemblages are detected at very fine scales (e.g. Carvalho et al., 2011). They have been found to be extremely sensitive to habitat structure and disturbance (Cardoso et al., 2010), the knowledge on their higher-order phylogeny is relatively stable (Coddington \& Levi, 1991) and their ways of life and functional roles in the ecosystems are relatively well-known (Cardoso et al., 2011c). All the knowledge accumulated on the group makes it relatively easy to study when compared with other mega-diverse orders. Finally, spiders constitute one of the main predator groups in most caves, occupying a place at the top of the simplified food chains of the subterranean environment.

The Iberian Peninsula is part of the Mediterranean Basin hotspot of global biodiversity (Myers et al., 2000), with high levels of endemism for many taxa, including spiders (Cardoso \& Morano, 2010). Its karstic regions are widespread, especially in the peripheral areas, and have been extensively studied by numerous speleology associations. Iberian cave spiders have been studied since the 1930's by different researchers, namely António de Barros Machado (e.g. Machado, 1939, 1942a, b; Machado \& Ribera, 1986) and Carles Ribera (e.g. Ribera, 1977, 1978, 1979a, b, 2004; Ribera et al., 2003). These authors, among sporadic work by others, have extensively sampled several karstic areas in the Peninsula.

The first objective of this work is to compare the ranges of epigean versus cave-obligate species of Iberian spiders. Given the isolation of karstic regions in the Iberian Peninsula and the low dispersal ability of troglobionts, I hypothesize that the typical ranges of troglobionts are considerably narrower. The second objective is to compare beta diversity values of epigean versus cave-obligate assemblages between different regions in the Iberian Peninsula. If the smaller ranges of troglobionts are verified, I hypothesize that beta diversity should be higher for this group than for epigean assemblages in the same regions. The third objective is to compare the phylogenetic and functional diversity of cave and epigean assemblages with consequent taxonomic and functional disharmony. Given the large scale of this study, that some families 
may not be pre-adapted for subterranean ways of life and that some foraging strategies may not be ideal in such habitat, I hypothesize that cave species are a non-random, low diversity, subset of all species in the Iberian Peninsula and that disharmony occurs at both levels, taxonomic and functional.

\section{METHODS}

\section{Dataset}

Of the 1347 species of spiders known to occur in the Iberian Peninsula, 236 (18\%) are endemic (Cardoso \& Morano, 2010; Morano \& Cardoso, 2011). I only considered endemic species for the range and beta diversity analyses so that all data ever published for each species could be included. The phylogenetic and functional diversity and disharmony analyses considered all species, endemic or not. All distribution data was georeferenced (Morano \& Cardoso, 2011). In this work, I followed the most recent definition of troglobiont by Sket (2008): a species strongly bound to hypogean habitats. I classified as troglobionts all species with at least $80 \%$ of records in caves, as specified in the Iberian Spider Catalogue habitat data (Morano \& Cardoso, 2011). The 80\% threshold was used so that uncertain records would not classify as epigean some troglobiont species that have been recorded in the literature only with the closest locality name and not the cave name. Therefore, the true percentage of records in caves for many such species should be higher.

\section{Range}

The knowledge on the distribution of most species, especially invertebrates, is incomplete. This is the so-called "Wallacean shortfall" (Lomolino, 2004; Cardoso et al., 2011b). When sampling is incomplete, sampling effort is one, if not the main, determinant of species richness (Colwell \& Coddington, 1994; Coddington et al., 2009) and beta diversity (Cardoso et al., 2009) in all habitats, including in caves (Culver et al., 2004; Zagmajster et al., 2008, 2010). In order to compare the ranges of epigean and cave species, the sampling effort should be similar for both groups. As a measure of effort, I calculated the number of records (known caves/sites) per species, according to the distribution data available at the Iberian Spider Catalogue (Morano \& Cardoso, 2011). The median number of records per species was compared between groups with the Mann-Whitney U statistic. Abundance classes (octaves) were also calculated for the number of records of both groups. The frequency of abundance classes was compared by randomly resampling 999 times the epigean species to the same number as cave species, and obtaining the $95 \%$ upper and lower confidence limits for each class, equivalent to the 97.5 and 2.5 percentiles, respectively.

The remaining statistics were calculated only for species with at least four records. Although the distribution of some species may in fact encompass only a single or very few sites (Christman et al., 2005; Borges et al., subm.), to guarantee that any patterns found in the analyses were not due to undersampling, species with fewer than four records were considered as undersampled, as their distribution could be grossly underestimated.
The extent of occurrence (EOO) of each species was estimated as the area of the convex hull comprising all its records. The median EOO of epigean and cave species was compared between groups with the Mann-Whitney U statistic. Abundance classes (octaves) were also calculated for the EOO of both groups. The frequency of abundance classes was compared, as above, by randomly re-sampling 999 times the epigean species to the same number as cave species and obtaining the 95\% confidence limits for each class.

It is important to notice that the karstic regions in the Iberian Peninsula cover the entire ranges of latitude and longitude, from North to South and West to East, even though mostly in peripheral regions. The maximum EOO value possible to reach by any endemic species, either epigean or troglobiont, was therefore very similar.

\section{Beta diversity}

To compare beta diversity in epigean versus cave endemic species I made pairwise comparisons of the 13 Iberian provinces with at least two cave obligate species recorded. Many different options exist for beta-diversity evaluation based on incidence data (Kolleff et al., 2003). For this work I used the $\beta_{-3}$ index of Williams et al. (1996) as modified by Cardoso et al. (2009):

(Eq. 1) $\boldsymbol{R}_{-3}=2 \frac{\min (b, c)}{a+b+c}$

where: $\mathrm{a}=$ species shared by both assemblages; $\mathrm{b}$, $\mathrm{c}=$ species exclusive to each of the two compared assemblages. This index has the advantages over other indices that it does not consider species richness differences between sites (Carvalho et al., 2012) and is therefore particularly insensitive to undersampling (Cardoso et al., 2009). Because all provinces in the Iberian Peninsula are undersampled to a variable degree (Cardoso \& Morano, 2010), this robustness of the index was necessary.

The beta diversity of both epigean and cave faunas was calculated for each of the 78 possible pairs of provinces. The number of pairs for which cave assemblages presented higher beta diversity values than epigean assemblages was accounted for. To test for significance of differences, I used 999 randomizations where beta diversity pairs were randomly assigned and the number of pairs for which beta diversity for caves was higher than the beta diversity for epigean assemblages was calculated. The difference was considered significant if the observed value was higher than the 97.5 percentile of the randomization values.

\section{PD, FD and disharmony}

To find if environmental filtering caused taxonomic and/or functional clustering and disharmony, I tested if epigean and cave assemblages were non-random subsets of all Iberian species in their taxonomic and functional attributes, leading to lower phylogenetic diversity (PD) and functional diversity (FD) than expected by chance from the complete set of species in the Iberian Peninsula. 
A surrogate phylogenetic dendrogram was built based on the taxonomic classification of all Iberian species. In this dendrogram, species in the same genus were separated by a distance of 0.25 , species in different genera but the same family were separated by a distance of 0.5 , species in different families but the same suborder were separated by a distance of 0.75 and species in different suborders were separated by a distance of 1 (see Warwick \& Clarke, 1995, 1998; Clarke \& Warwick, 1998, 1999). The taxonomic (or phylogenetic) diversity of an assemblage was the sum of lengths of the branches connecting all its species (the PD measure of Faith, 1992, 1994; see also Rodrigues \& Gaston, 2002). To test if epigean and cave species were random subsets of the full Iberian taxonomic tree, I repeatedly (999 times) randomly subsampled $\mathrm{n}$ species from the tree, where $\mathrm{n}$ equals either epigean or cave species richness, and calculated PD for each random assemblage. The null hypothesis of random subsets was rejected if the observed PD for each assemblage was higher than the 97.5 percentile or lower than the 2.5 percentile of the 999 randomizations.

Functional non-randomness was tested much in the same way as taxonomic non-randomness. For each species, I compiled information on foraging strategy (type of web or method of active hunting), prey range (either stenophagous or euryphagous), vertical stratification (ground or vegetation), circadian activity (diurnal or nocturnal) and body size (average between males and females). Most data was based on a recent study on global spider functional diversity patterns (Cardoso et al., 2011c). Body size was compiled from a vast amount of literature, from field guides to taxonomic descriptions. Although many options exist for calculating FD (Petchey \& Gaston, 2006; Podani \& Schmera, 2006), for consistency I used a similar method to the calculations of PD. A functional dendrogram was built by cluster analysis using UPGMA with euclidean distances. FD was calculated as the sum of lengths of the branches connecting all species in a particular assemblage (Petchey \& Gaston, 2002). Significance was calculated as for PD.

Taxonomic disharmony was tested at the family level. The proportion of species per family of epigean and troglobiont spiders was compared using the Spearman rank correlation coefficient. For this analysis I used only the eight most species-rich families when averaging the percentages of species per family considered as epigean and troglobiont. Only eight families were used so that rare families did not artificially decrease rank correlation values. These were: (1) Linyphiidae; (2) Dysderidae; (3) Theridiidae; (4) Nesticidae; (5) Gnaphosidae; (6) Salticidae; (7) Lycosidae; and (8) Leptonetidae.

Likewise, functional disharmony was tested using the Spearman correlation to compare the proportion of species per guild of epigean and troglobiont spiders. Guilds were defined according to Cardoso et al. (2011c). Eight guilds were discriminated and are followed here: (1) sensing web weavers; (2) sheet web weavers; (3) space web weavers; (4) orb web weavers; (5) specialists; (6) ambush hunters; (7) ground hunters; and (8) other hunters.

\section{RESULTS}

The complete Iberian Peninsula spiders dataset included 1298 species classified as epigean and 49 as troglobiont, of which 199 (15\% of all epigean) and 37 ( $76 \%$ of all troglobiont) were endemic (Table 1). Some of the troglobiont species considered as non-endemic (e.g. Telema tenella or Iberina mazarredoi), have in fact restricted distributions but are Pyreneean that also live in the French part of the mountain chain. Total and endemic troglobiont richness was higher in northern and eastern provinces (Fig. 1).

Table 1. Iberian species classified as troglobiont in this work with corresponding family and guild (see Cardoso et al., 2011c for guild definition).

\begin{tabular}{lll}
\hline Family & Species & Guild \\
Agelenidae & Tegenaria hispanica & Sheet \\
Dysderidae & Dysdera bicornis & Specialist \\
Dysderidae & Dysdera espanoli & Specialist \\
Dysderidae & Dysdera valentina & Specialist \\
Dysderidae & Dysdera vivesi & Specialist \\
Dysderidae & Harpactea ortegai & Ground \\
Dysderidae & Harpactea stalitoides & Ground \\
Dysderidae & Speleoharpactea levantina & Ground \\
Leptonetidae & Leptoneta comasi & Space \\
Leptonetidae & Leptoneta leucophthalma & Space \\
Leptonetidae & Teloleptoneta synthetica & Space \\
Linyphiidae & Centromerus andrei & Sheet \\
Linyphiidae & Centromerus viduus & Sheet \\
Linyphiidae & Iberoneta nasewoa & Other \\
Linyphiidae & Lepthyphantes balearicus & Sheet \\
Linyphiidae & Lepthyphantes bidentatus & Sheet \\
Linyphiidae & Lepthyphantes fagei & Sheet \\
Linyphiidae & Lepthyphantes gadesi & Sheet \\
Linyphiidae & Lepthyphantes ibericus & Sheet \\
Linyphiidae & Lepthyphantes phallifer & Sheet \\
Linyphiidae & Lepthyphantes zaragozai & Sheet \\
Linyphiidae & Palliduphantes cortesi & Sheet \\
Linyphiidae & Palliduphantes gypsi & Sheet \\
Linyphiidae & Palliduphantes lorifer & Sheet \\
Linyphiidae & Trichoncus pinguis & Other \\
Linyphiidae & Troglohyphantes affirmatus & Sheet \\
Linyphiidae & Troglohyphantes bolivarorum & Sheet \\
Linyphiidae & Troglohyphantes cantabricus & Sheet \\
Linyphiidae & Troglohyphantes nyctalops & Sheet \\
Nesticidae & Nesticus luquei & Space \\
Nesticidae & Nesticus lusitanicus & Space \\
Nesticidae & Nesticus murgis & Space \\
Nesticidae & Nesticus obcaecatus & Space \\
Pimoidae & Pimoa breuili & Sheet \\
Symphytognathidae & Anapistula ataecina & Sheet \\
Theridiidae & Robertus cantabricus & Space \\
Theridiidae & Robertus cardesensis & Space \\
\hline & & \\
\hline & &
\end{tabular}


a)

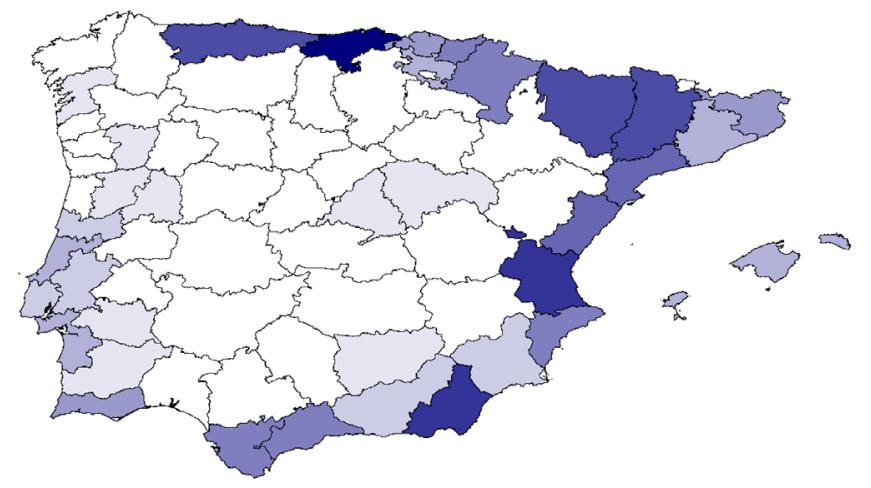

Fig. 1. (a) Total and (b) endemic cave-obligate spider species richness per province. Darker shades represent higher values.

\section{Range}

Although the average number of records per species was higher for epigean (9.096) than for cave taxa (5.459), the median was equal (3) and the difference was not significant (Mann-Whitney $\mathrm{U}=3035$, $\mathrm{p}=0.090$ ). The distribution of records per species in octaves was relatively similar between groups (Fig. 2). Although troglobionts presented a higher frequency of the first and third octaves and epigean species had a higher number of species between 8 and 31 records, no differences were significant, except in the 16 to 31 records class, which presented higher values for epigean species. Ninety-nine epigean and 15 cave species had at least four records and were used in the EOO analyses.

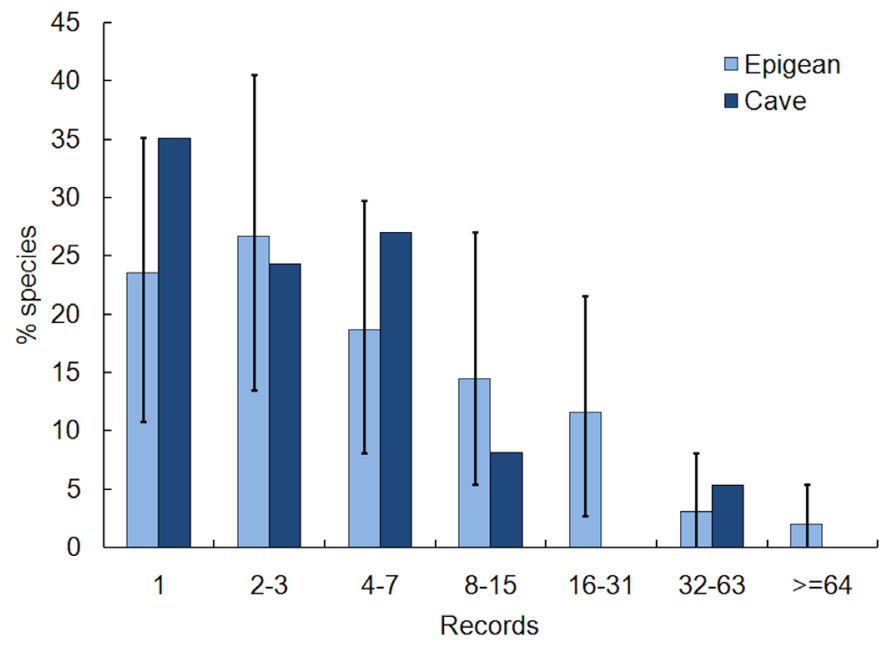

Fig. 2. Abundance classes (octaves) of the number of published records of epigean and cave-obligate Iberian endemic spider species. Error bars indicate the 95\% confidence limits for epigean species when re-sampled to the number of cave species.

The median EOO was 33 times higher for epigean species $\left(30160 \mathrm{~km}^{2}\right)$ than for cave species $\left(910 \mathrm{~km}^{2}\right)$. This difference was highly significant (Mann-Whitney U $=246, p<0.001)$. The distribution of EOO frequencies in octaves reflected this dissimilarity, with significant differences in most classes (Fig. 3). Although most epigean species had EOOs above $10000 \mathrm{~km}^{2}$, most cave species had much lower values, with a minimum of $1 \mathrm{~km}^{2}$ for Anapistula ataecina.

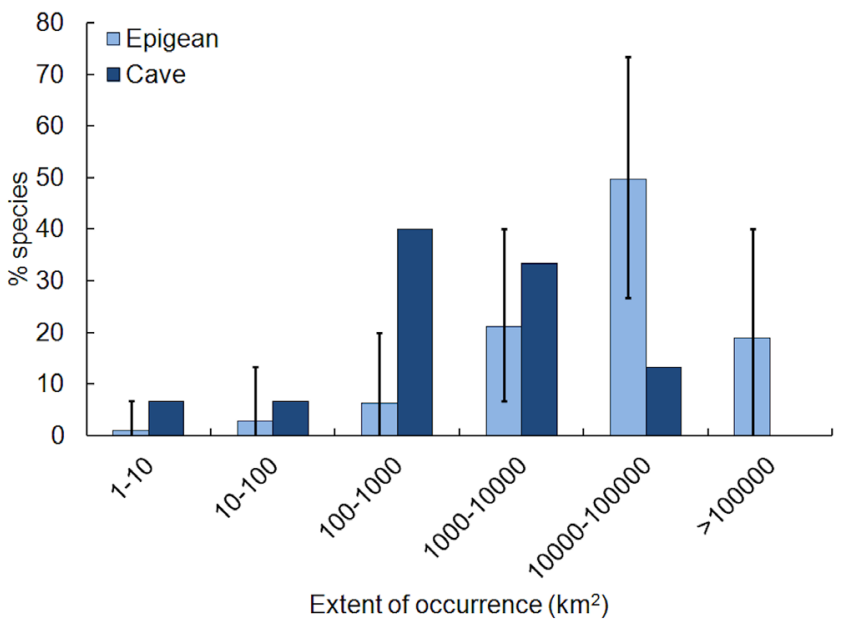

Fig. 3. Abundance classes (octaves) of the extent of occurrence of epigean and cave-obligate Iberian endemic spider species. Only species with at least four records were considered. Error bars indicate the $95 \%$ confidence limits for epigean species when resampled to the number of cave species.

\section{Beta diversity}

Beta diversity between Iberian provinces was generally higher for cave than for epigean assemblages. The values for epigean spiders varied between 0 and 0.92 , while the values for troglobionts mostly varied between 0.5 and 1 (with two exceptions for which $\beta-3=0)$. Sixty-six out of 78 pairwise beta diversity values were higher for troglobionts than for epigeans, three were similar and for the remaining nine, beta diversity of epigean assemblages was higher (Fig. 4). The randomizations showed that this difference was highly significant $(\mathrm{p}<0.001)$.

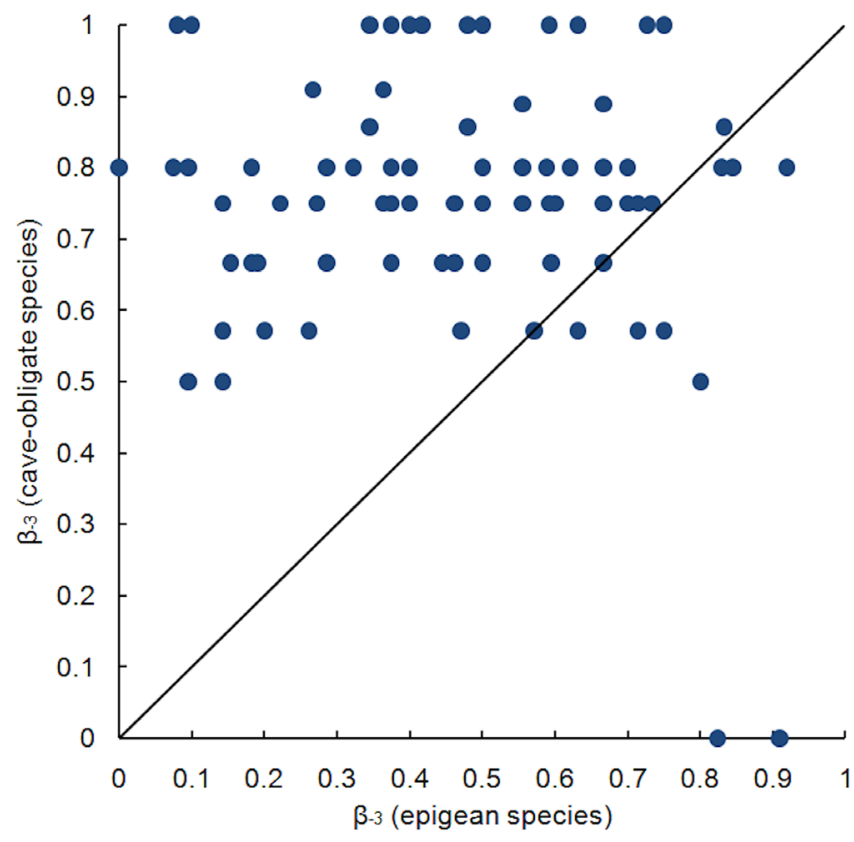

Fig. 4. Beta diversity values for epigean and cave-obligate Iberian endemic spider assemblages, as calculated with the Williams $\beta_{-3}$ index, between pairs of provinces in the Iberian Peninsula. Only provinces with at least two recorded endemic troglobiont species were considered. The diagonal represents similar values of beta diversity for both taxa. 


\section{PD, FD and disharmony}

Both epigean $(p=0.006)$ and cave $(p<0.001)$ assemblages were found to be non-random taxonomic subsets of the full Iberian spiders assemblage (Fig. 5), with lower PD than expected by chance. The same was verified for the functional attributes of both epigean $(0.002)$ and cave $(p<0.001)$ species (Fig. 6), with lower FD than expected by chance. Parts of the taxonomic and functional trees were occupied by either one or the other, although cave species were necessarily more clustered, not occupying the majority of the branches in both trees.

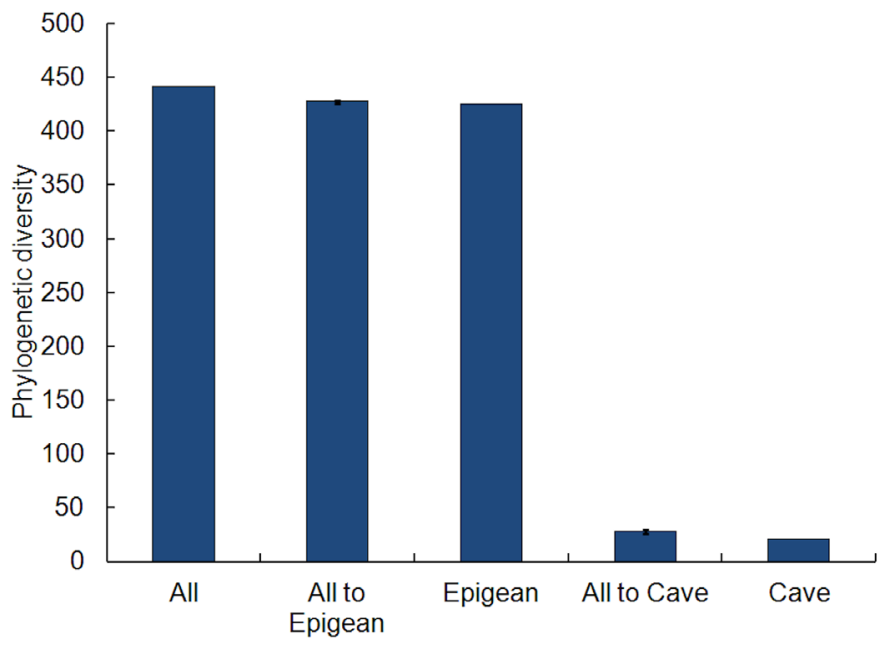

Fig. 5. Phylogenetic diversity (PD) of all, epigean and cave-obligate Iberian spiders, and expected PD if epigean and cave species were random subsets of the entire dataset (with 95\% confidence limits). All differences are significant $(p<0.05)$.

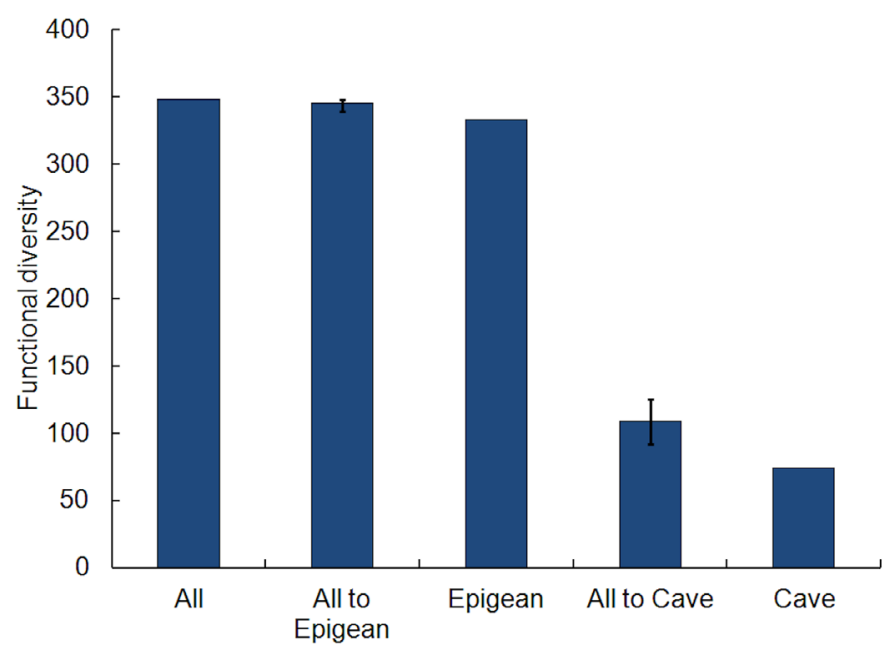

Fig. 6. Functional diversity (FD) of all, epigean and cave-obligate Iberian spiders, and expected FD if epigean and cave species were random subsets of the entire dataset (with 95\% confidence limits). All differences are significant $(p<0.05)$.

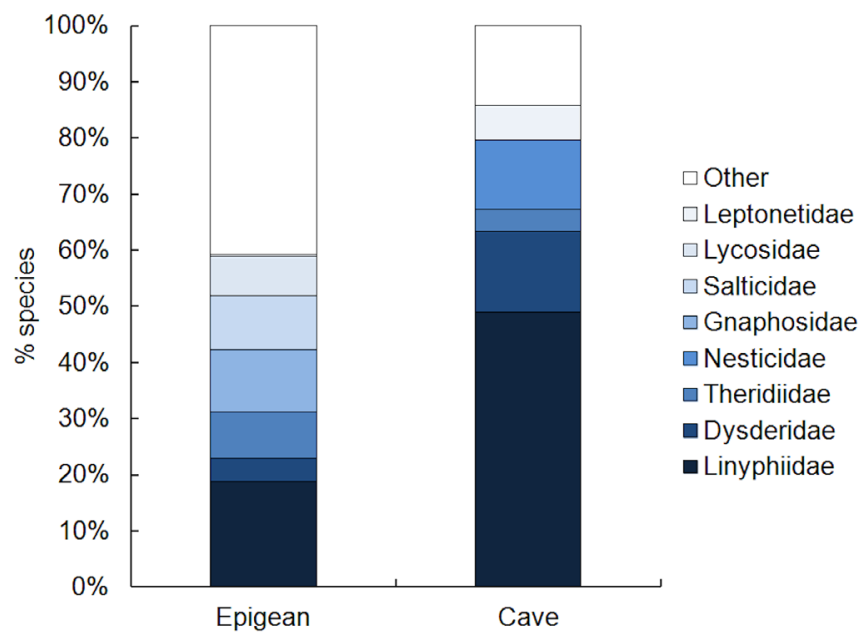

Fig. 7. Proportion of epigean and cave-obligate Iberian spider species per family.

Of the 55 families known from the Iberian Peninsula, 51 had epigean representatives and only 11 families had troglobiont species. Linyphiidae was the most species rich family in both cases (Fig. 7). However, the relative richness of all other families differed considerably. Among the most species rich families at each habitat, gnaphosids, salticids and lycosids were absent in caves, while nesticids, pimoids, symphytognathids and telemids were absent from above the surface. As a consequence, there was no correlation in family richness rankings (Spearman $R=-0.171 ; p=0.686)$.

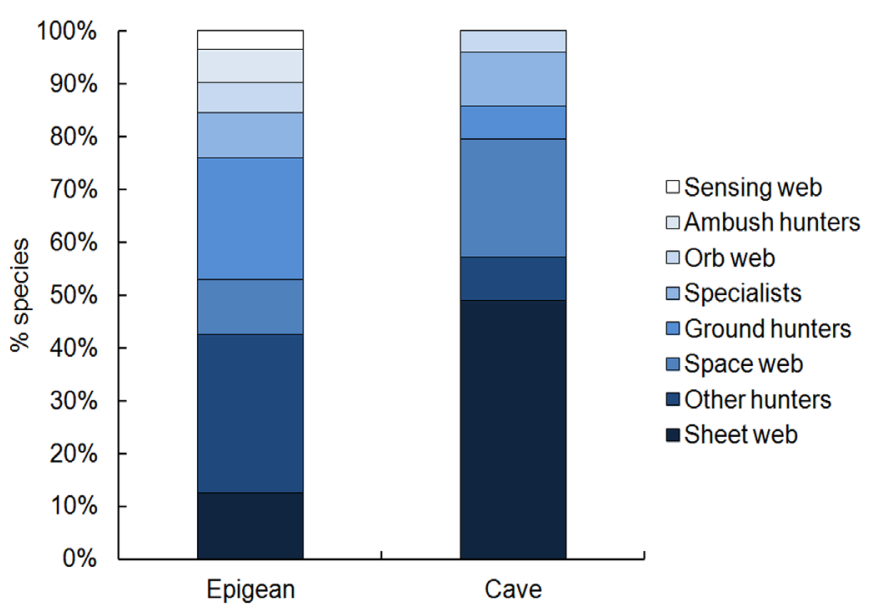

Fig. 8. Proportion of epigean and cave-obligate Iberian spider species per guild.

Among the eight guilds, active hunters were more species-rich above the surface, while sheet and space web builders were the most species-rich in caves (Fig. 8). Specialists and orb web weavers had similar proportions in both realms. Ambush hunters and sensing web weavers were completely absent in caves. There was no significant correlation in guild richness rankings (Spearman $\mathrm{R}=0.599 ; \mathrm{p}=0.117$ ) 


\section{DISCUSSION}

Most of the endemic or non-endemic richness of cave-obligate spiders in the Iberian Peninsula concentrates in provinces with large karstic areas, as the availability of habitat often is the main determinant of the species richness of troglobionts (Christman \& Culver, 2001; Culver et al., 2003, 2004). As in true islands, larger areas provide more carrying capacity for a higher number of species, more opportunities for isolation and higher habitat diversity. At the small scale of a cave or cave system, the richness is invariably low. The maximum number of troglobiont spider species known from a single cave in the region is three (Morano \& Cardoso, 2011). This is two orders of magnitude lower than the more than 200 species found in a single hectare of many habitat types on the surface (Cardoso, 2009). Being top predators, among the few in many caves, troglobiont spiders are limited by the availability of other invertebrates. Each cave has a limited capacity to host more than a very few species of spiders.

In the Iberian spiders' dataset, as is common for many taxa and regions (e.g., see Sket, 1999 for European stygobionts), the proportion of endemics is considerably higher for troglobionts than for epigean species. Also, as expected, the range of troglobionts is extremely narrow when compared to the typical range of epigean spiders. Although future sampling will certainly increase the known EOO for many species (Culver et al., 2004; Ferreira et al., 2007), this will occur for both cave and epigean species. Habitat fragmentation of the subterranean realm usually causes stronger isolation than in the epigean realm and drives allopatric speciation. Additionally, intrinsic factors, such as low vagility and high habitat specialization contribute to the differences between the subterranean and epigean realms (Crouau-Roy, 1989; Holsinger, 1991; Gibert et al., 1994).

If the range of troglobionts is much narrower than that of their epigean counterparts, beta diversity is, as expected, higher. The replacement of species from one region to the closest is usually high, with only a few species being present in larger areas. Even inside the same karstic region it is common to experience such large replacement levels. As an example, the Arrábida karstic area, $20 \mathrm{kms}$ south of Lisbon, Portugal, has about $50 \mathrm{~km}^{2}$. It has been extensively studied and two distinct regions can be differentiated (Cardoso et al., unpublished data). The western half, from Cape Espichel to Sesimbra, is characterized by the existence of a number of strict endemics, such as the spider Anapistula ataecina, limited to the Frade cave system (Cardoso \& Scharff, 2009). Many more species, not only of spiders, are still to be described from this area and are known from single caves, such as a pseudoscorpion Chthonius n.sp. known only from Gruta do Fumo (Zaragoza, in prep.) and a diplopod Dolistenus n.sp. known only from Lapa do Vento (Mauriès, in prep.). The Eastern half, from Sesimbra to Palmela/Setúbal, is characterized by the presence of more widespread species, some endemic, such as the leptonetid Teloleptoneta synthetica, which is relatively widespread throughout Southern Portugal down to Algarve.
Often only a fraction of the species found inside caves, especially closer to entrances, is cave-obligate (e.g. Sharratt et al., 2000). Deeper areas are however the true realm of troglobiont and stygobiont species and the assemblages they form typically present a very marked taxonomic and functional disharmony (Gibert \& Deharveng, 2002). Some epigean taxa can be considered as pre-adapted to subterranean life. These are eutroglophiles (as defined by Sket, 2008) and often live in the Superficial Subterranean Habitats (SSH) for at least part of their life-cycle. These include small emerging drainages (hypotelminorheic), small cavities in the uppermost karst layers (epikarst), talus slopes or surface cracks and fissures (mesovoid shallow substratum - MSS; Juberthie, 1983; Culver, 2001; Oromí, 2004; Culver \& Pipan, 2008; Pipan et al., 2011). Pre-adaptation seems important for cave living (Christiansen, 1992) and only a few taxa have it. As an example, among Coleoptera, the Carabidae (mostly Trechinae) and Cholevidae (mostly Leptodirinae) dominate among the subterranean species (Juberthie \& Decu, 1998). Only a few spider families include species able to live in such conditions and these are able to occupy caves if the surface climate changes radically or in search of unexplored ecological niches. Many species are relicts, whose ancestors have colonized the subterranean habitat but declined to extinction at the surface (Holsinger, 1991). Currently, four spider familes are restricted to caves in the Iberian Peninsula, even if they have possibly occupied the surface before the quaternary glaciations and epigean representatives are now restricted to southern latitudes (e.g. Cardoso \& Scharff, 2009). On the other hand, if some taxa are pre-adapted to cave-living, they are able to persist and diversify with little competition, giving origin to different species in different karstic regions. As observed for, e.g., European stygobionts, the lack of some taxa in the habitat creates opportunities for other taxa, as the lack of insects in European underground waters enabled the rise of crustacean diversity (Sket, 1999). This seems to be the case of seven different Iberian cave-obligate species of Leptyphantes, four Troglohyphantes and three Palliduphantes, all linyphiid spiders previously included in the first genus.

Functional disharmony was found to be as important in Iberian cave spiders as taxonomic disharmony. In fact, the differences in functional composition of assemblages are so marked, that are much higher between epigean and cave species in the same region than between forest sites in different parts of the world, whose assemblages maintain their guild composition despite large changes in family composition (Cardoso et al., 2011c). The subterranean habitat lacks entire guilds, as either the type of web is impossible to build in a cave (sensing web weavers) or the hunting strategy would not be efficient in an habitat with little abundance of prey (ambush hunters). The scarce opportunity for active prey hunting in fact seems to dictate the low diversity of species using this strategy compared with the surface assemblages. The types of web that are previleged in the subterranean habitat are especially useful for crawling insects (sheet and space webs, see Cardoso et 
al., 2011c), in detriment of webs exclusively targeting flying insects (orb webs), as these insects are rare in deep caves. In support of this argument, while most symphytognathids, namely the genus Anapistula, are orb weavers (Cardoso et al., 2011c), the only Iberian species is a sheet web weaver in caves, probably due to its habitat requirements (Cardoso \& Scharff, 2009). Given the low availability of energy in caves, many lineages are forced to broaden their diets and specialization is relatively rare (Gibert \& Deharveng, 2002). The relatively high proportion of specialists found is therefore intriguing. It is possible that Dysdera, which are specialist isopod hunters on the surface, are in fact generalist hunters in caves. Little is known about their ecology in the Iberian Peninsula and the classification I have used may in fact be erroneous, as it is based on what is generally known about the genus.

Both taxonomic and functional disharmony, caused by environmental filtering and consequent taxonomic and functional clustering of species, may however be dependent on the spatial scale. Further studies would be needed to know if in small spatial scales such as a single cave or karstic region the same results would be obtained. Possibly, competitive exclusion would play a larger role in community assembly and the disharmony found for Iberian spiders would be attenuated if not inexistent (Cavender-Bares et al., 2009; Pausas \& Verdú, 2010).

It should be mentioned that the conservation of invertebrate cave species is often complicated by the lack of knowledge on their distribution, abundances and sensitivity to habitat change (Cardoso etal., 2011b). Caves are a particularly challenging medium to work at because: (1) many, if not most, caves are unknown (no known entrances); (2) among the known, many are difficult to access and work in; (3) caves are only the accessible part of the subterranean environment, micro $(<1 \mathrm{~mm}$ diameter) and mesocavernous $(<20 \mathrm{~cm}$ diameter) areas are impossible to reach by humans, unless by indirect means (baited traps, percolation devices, etc.); (4) troglobiont populations are usually of low abundance, making it difficult to assess their diversity even in small caves or regions (Schneider and Culver, 2004); and (5) due to the low abundances, some collecting techniques must be used with caution or even avoided (e.g. long-term baited pitfall traps).

With restricted ranges (due to the isolation between cave systems and low vagility), low population abundances (due to low energy availability) and restricted habitat (by definition), cave organisms often fulfill all existing forms of rarity (Rabinowitz, 1981; Gaston, 1994). Some of the differences here discussed between epigean and cave spiders indeed point to a higher vulnerability of troglobionts, with higher risk of extinction in general. First, low diversity implies simplified food chains. There is less redundancy in the roles of species which probably leads to higher danger of community disruption (Chapin et al., 1997; Tilman et al., 1997; Loreau et al., 2001; Petchey, 2004; Laliberté et al., 2010). Second, the smaller ranges are necessarily linked to higher vulnerability (IUCN, 2010, Cardoso et al., 2011a). In a recent study of eight troglobiont Iberian spiders that were evaluated according to the current IUCN criteria (IUCN, 2010), all species fulfilled the EOO criteria for considering them endangered (Cardoso et al., 2011a). Third, the higher fragmentation leads to fewer opportunities for rescue effects of sink populations from sources with higher abundance of individuals. Cave species are therefore particularly vulnerable to disturbance that may disrupt assemblages at small spatial or temporal scales (Slaney \& Weinstein, 1997). Fourth, the uniqueness in the taxonomical composition of communities, with relict families that are not found on the surface, makes them especially important as troglobiont species harbour unique phylogenetic diversity. Additionally, the characteristics of troglobionts generally put them in high danger of extinction due to global warming (Cardoso et al., subm.). As a consequence of their particular vulnerability, troglobionts often are in fact important parts of red lists (IUCN, 2010) and their listing in legally protected species lists has been repeatedly advocated (Martín et al., 2010; Cardoso, 2012). The only Iberian spider currently listed by the International Union for the Conservation of Nature (IUCN), Anapistula ataecina, is a troglobiont. In the meanwhile, as our knowledge on Iberian cave spider fauna increases slowly, it may occur that many species go extinct even before they are described, the so-called Linnean extinctions (Ladle \& Jepson, 2008; Cardoso et al., 2010, 2011b).

\section{ACKNOWLEDGEMENTS}

The author is supported by the Portuguese Foundation for Science and Technology (SFRH/ BPD/40688/2007).

\section{REFERENCES}

Anderson M.J., Crist T.O., Chase J.M., Vellend M., Inouye B.D., Freestone A.L., Sanders N.J., Cornell H.V., Comita L.S., Davies K.F., Harrison S.P., Kraft N.J.B., Stegen J.C. \& Swenson N.G., 2011 Navigating the multiple meanings of beta diversity: a roadmap for the practicing ecologist. Ecology Letters, 14: 19-28.

http://dx.doi.org/10.1111/j.1461-0248.2010.01552.x

Barr T.C. \& Holsinger J.R., 1985 - Speciation in cave faunas. Annual Review of Ecology and Systematics, 16: 313-317.

http://dx.doi.org/10.1146/annurev.es.16.110185.001525

Borges P.A.V., Pereira F. \& Constância J.P., 2007 Indicators of conservation value of Azorean caves based on its arthropod fauna. Proceedings of the Xth, XIth and XIIth International Symposium on Vulcanospeleology, AMCS Bulletin, 19: 109-113.

Borges P.A.V., Cardoso P., Amorim I.R., Pereira F., Constância J.P., Nunes J.C., Barcelos P., Costa P., Gabriel R. \& Dapkevicius M.L., subm. - Volcanic cave priorities for conserving the Azorean endemic troglobiont species. International Journal of Speleology.

Cardoso P., 2009 - Standardization and optimization of arthropod inventories - the case of Iberian spiders. Biodiversity and Conservation, 18: 3949-3962. http:/ /dx.doi.org/10.1007/s10531-009-9690-7

Cardoso P., 2012 -Habitats Directive specieslists:urgent need of revision. Insect Conservation and Diversity. http://dx.doi.org/10.1111/j.1752-4598.2011.00140.x 
Cardoso P. \& Morano E., 2010 - The Iberian spider checklist (Araneae). Zootaxa, 2495: 1-52.

Cardoso P. \& Scharff N., 2009 - First record of the spider family Symphytognathidae in Europe and description of Anapistula ataecina sp. n. (Araneae). Zootaxa, 2246: 45-57.

Cardoso P., Borges P.A.V. \& Veech, J.A., 2009 - Testing the performance of beta diversity measures based on incidence data: the robustness to undersampling. Diversity and Distributions, 15: 1081-1090. http://dx.doi.org/10.1111/j.1472-4642.2009.00607.x

Cardoso P., Arnedo M.A., Triantis K.A. \& Borges P.A.V., 2010 - Drivers of diversity in Macaronesian spiders and the role of species extinctions. Journal of Biogeography, 37: 1034-1046. http://dx.doi.org/10.1111/j.1365-2699.2009.02264.x

Cardoso P., Borges P.A.V., Triantis K.A., Ferrández M.A. \& Martín J.L., 2011 a - Adapting the IUCN red listing criteria for invertebrates. Biological Conservation, 144: 2432-2440. http://dx.doi.org/10.1016/j.biocon.2011.06.020

Cardoso P., Erwin T.L., Borges P.A.V. \& New T.R., $2011 \mathrm{~b}$ - The seven impediments in invertebrate conservation and how to overcome them. Biological Conservation, 144: 2647-2655. http://dx.doi.org/10.1016/j.biocon.2011.07.024

Cardoso P., Pekár S., Jocqué R. \& Coddington J.A., 2011c - Global patterns of guild composition and functionaldiversity ofspiders. PLoSONE, 6: e21710. http://dx.doi.org/10.1371/journal.pone.0021710

Cardoso P., Amorim I.R., Hedin M., Pereira F. \& Borges P.A.V., subm. - Global warming as an extinction driver of cave obligate species. Global Change Biology.

Carvalho J.C., Cardoso P., Crespo L.C., Henriques S., Carvalho R. \& Gomes P., 2011 - Biogeographic patterns of spiders in coastal dunes along a gradient of mediterraneity. Biodiversity and Conservation, 20: 873-894.

http://dx.doi.org/10.1007/s10531-011-0001-8

Carvalho J.C., Cardoso P. \& Gomes P., 2012 - Determining the relative roles of species replacement and species richness differences in generating beta-diversity patterns. Global Ecology and Biogeography, http://dx.doi.org/10.1111/j.1466-8238.2011.00694.x

Cavender-Bares J., Kozak K.H., Fine P.V.A. \& Kembel S.W., 2009 - The merging of community ecology and phylogenetic biology. Ecology Letters, 12: 693-715. http://dx.doi.org/10.1111/j.1461-0248.2009.01314.x

Chapin F.S., Walker B.H., Hobbs R.J., Hooper D.U., Lawton J.H., Sala O.E. \& Tilman D., 1997 - Biotic control over the functioning of ecosystems. Science, 277: 500-504.

http://dx.doi.org/10.1126/science.277.5325.500

Christiansen K., 1992 - Biological processes in space and time. Cave life in the light of modern evolutionary theory. In: Camacho A.I. (Ed.) - The Natural History of Biospeleology. Madrid: Museo Nacional de Ciencias Naturales: 453-478.

Christman M.C. \& Culver D.C., 2001 - The relationship between cave biodiversity and available habitat. Journal of Biogeography, 28: 367-380. http://dx.doi.org/10.1046/j.1365-2699.2001.00549.x
Christman M.C., Culver D.C, Madden M.K. \& White D., 2005 - Patterns of endemism of the eastern North American cave fauna. Journal of Biogeography, 32: 1441-1452.

http://dx.doi.org/10.1111/j.1365-2699.2005.01263.x

Clarke K.R. \& Warwick R.M., 1998 - A taxonomic distinctness index and its statistical properties. Journal of Applied Ecology, 35: 523-531. http://dx.doi.org/10.1046/j.1365-2664.1998.3540523.x

Clarke K.R. \& Warwick R.M., 1999 - The taxonomic distinctness measure of biodiversity: weighing of step lengths between hierarchical levels. Marine Ecology Progress Series, 184: 21-29. http:/ /dx.doi.org/10.3354/meps 184021

Coddington J.A. \& Levi H.W., 1991 - Systematics and Evolution of Spiders (Araneae). Annual Review of Ecology and Systematics, 22: 565-592. http://dx.doi.org/10.1146/annurev.es.22.110191.003025

Coddington J.A., Agnarsson I., Miller J.A., Kuntner M. \& Hormiga G., 2009 - Undersampling bias: the null hypothesis for singleton species in tropical arthropod surveys. Journal of Animal Ecology, 78: 573-584. http://dx.doi.org/10.1111/j.1365-2656.2009.01525.x

Colwell R.K. \& Coddington J.A., 1994 - Estimating terrestrial biodiversity through extrapolation. Philosophical Transactions: Biological Sciences, 345: 101-118.

http:/ /dx.doi.org/10.1098/rstb.1994.0091

Crouau-Roy B., 1989 - Population studies on an endemic troglobitic beetle: geographical patterns of genetic variation, gene flow and genetic structure compared with morphometric data. Genetics, 121: 571-582.

Culver D.C., 2001 - Subterranean ecosystems. In: Levin, S.A. (Ed.) - Encyclopedia of Biodiversity $V$. San Diego: Academic Press: 527-540.

Culver D.C. \& Pipan T., 2008 - Superficial subterranean habitats - gateway to the subterranean realm? Cave and Karst Science, 35: 5-12.

Culver D.C. \& Pipan T., 2009 - The Biology of Caves and other Subterranean Habitats. Oxford: University Press.

Culver D.C., Master L.L., Christman M.C. \& Hobbs III H.H., 2000 - Obligate cave fauna of the 48 contiguous United States. Conservation Biology, 14: 386-401. http://dx.doi.org/10.1046/j.1523-1739.2000.99026.x

Culver D.C., Christman M.C., Elliott W.R., Hobbs III H.H. \& Reddell J.R., 2003 - The North American obligate cave fauna: regional patterns. Biodiversity and Conservation, 12: 441-468. http://dx.doi.org/10.1023/A:1022425908017

Culver D.C., Christman M.C., Sket B. \& Trontelj P., 2004 - Sampling adequacy in an extreme environment: species richness patterns in Slovenian caves. Biodiversity and Conservation, 13: 1209-1229. http://dx.doi.org/10.1023/B:BIOC.0000018153.49280.89

Faith D.P., 1992 - Conservation evaluation and phylogenetic diversity. Biological Conservation, 61: 1-10. http://dx.doi.org/10.1016/0006-3207(92)91201-3

Faith D.P., 1994 - Phylogenetic pattern and the quantification of organismal biodiversity. Philosophical Transactions:Biological Sciences, 345: 45-58. http://dx.doi.org/10.1098/rstb.1994.0085 
Ferreira D., Malard F., Dole-Olivier M.J. \& Gibert J., 2007 - Obligate groundwater fauna of France: diversity patterns and conservation implications. Biodiversity and Conservation, 16: 567-596. http://dx.doi.org/10.1007/s10531-005-0305-7

Gaston K.J., 1994 - Rarity. London: Chapman and Hall.

Gibert J. \& Deharveng L., 2002 - Subterranean ecosystems: a truncated functional biodiversity. Bioscience, 52: 473-481.

Gibert J., Danielopol D.L. \& Stanford J.A., 1994 Groundwater Ecology. New York: Academic Press.

Gillespie R.G. \& Roderick G.K., 2002 - Arthropods on islands: evolution and conservation. Annual Review of Entomology, 47: 595-632.

http://dx.doi.org/10.1146/annurev.ento.47.091201.145244

Holsinger J.R., 1991 - What can vicariance biogeographic models tell us about the distributional history of subterranean amphipods? Hydrobiologia, 223: 43-45. http:/ / dx.doi.org/10.1007 /BF00047627

Howarth F.G., 1983 - Ecology of cave arthropods. Annual Review of Entomology, 28: 365-389. http://dx.doi.org/10.1146/annurev.en.28.010183.002053

IUCN, 2010 - IUCN Red List of Threatened Species. Version 2010.4. Available online at: http://www. iucnredlist.org. Downloaded on 01 April 2011.

Juberthie C., 1983 - Le milieu souterrain: étendue et composition. Memoires de Biospéologie, 10: 1765.

Juberthie C. \& Decu V. (eds.), 1998 - Encyclopaedia Biospeologica II. Moulis- Bucarest: Société de Biospéléologie.

Kindle B.K. \& Kane T.C., 2000 - Chemolithotrophic microorganisms and their potential role in subsurface environments. In: Wilkens, H., Culver, D.C., Humphries, W.F. (Eds.). Ecosystems of the World, vol. 30. Amsterdam: Elsevier: 309-319.

Koleff P., Gaston K.J. \& Lennon J.J., 2003 - Measuring beta diversity for presence-absence data. Journal of Animal Ecology, 72: 367-382. http://dx.doi.org/10.1046/j.1365-2656.2003.00710.x

Ladle R.J. \& Jepson P., 2008 - Toward a biocultural theory of avoided extinction. Conservation Letters, $\mathbf{1}$ : 111-118.

http://dx.doi.org/10.1111/j.1755-263X.2008.00016.x

Laliberté E., Wells J.A., DeClerck F., Metcalfe D.J., Catterall C.P., Queiroz C., Aubin I., Bonser S.P., Ding Y., Fraterrigo J.M., McNamara S., Morgan J.W., Merlos D.S., Vesk P.A. \& Mayfield M.M., 2010 - Landuse intensification reduces functional redundancy and response diversity in plant communities. Ecology Letters, 13: 76-86. http://dx.doi.org/10.1111/j.1461-0248.2009.01403.x

Lamoreux J., 2004 - Stygobites are more wide-ranging than troglobites. Journal of Cave and Karst Studies, 66: 18-19.

Lomolino M.V., 2004 - Conservation biogeography, in: Lomolino M.V. \& Heaney L.R. (Eds.), Frontiers of Biogeography: new directions in the geography of nature. Sunderland, MA: Sinauer Associates: 293-296.
Loreau M., Naeem S., Inchausti P., Bengtsson J., Grime J.P., Hector A., Hooper D.U., Huston M.A., Raffaelli D., Schmid B., Tilman D. \& Wardle D.A., 2001 - Biodiversity and ecosystem functioning: Current knowledge and future challenges. Science, 294: 804-808. http:/ /dx.doi.org/10.1126/science.1064088

Machado A.B., 1939 - Trois nouvelles Araignees cavernicoles de l'Espagne. Bulletin de la Société Zoologique de France, 64: 60-70.

Machado A.B., 1942a - As cavernas de Portugal sob o ponto de vista biológico. Boletim da Sociedade Portuguesa de Ciencias Naturais, 13: 639-642.

Machado A.B., 1942b - A coleção de aranhas cavernicolas do Museo Nacional de Ciencias Naturais de Madrid. Anales de la Asociación Española para el Progreso de las. Ciencias, 7: 1-15.

Machado A.B. \& Ribera C., 1986 - Araneidos cavernicolas de Portugal: familia Leptonetidae (Araneae). Actas X Congreso Internacional de Aracnologia: 355-366.

Malard F., Boutin C., Camacho A.I., Ferreira D., Michel G., Sket B. \& Stoch F., 2009 - Diversity patterns of stygobiotic crustaceans across multiple spatial scales in Europe. Freshwater Biology, 54: 756-776. http://dx.doi.org/10.1111/j.1365-2427.2009.02180.x

Martín J.L., Cardoso P., Arechavaleta M., Borges P.A.V, Faria B.F., Abreu C., Aguiar A.F., Carvalho J.A., Costa A.C., Cunha R.T., Fernandes F.M., Gabriel R., Jardim R., Lobo C., Martins A.M.F., Oliveira P., Rodrigues P., Silva L., Teixeira D., Amorim I.R., Homem N., Martins B., Martins M. \& Mendonça E., 2010 - Using taxonomically unbiased criteria to prioritize resource allocation for oceanic island species conservation. Biodiversity and Conservation, 19: 1659-1682. http://dx.doi.org/10.1007/s 10531-010-9795-z

Michel G., Malard F., Deharveng L., Di Lorenzo T., Sket B. \& De Broyer C., 2009 - Reserve selection for conserving groundwater biodiversity. Freshwater Biology, 54: 861-876. http://dx.doi.org/10.1111/j.1365-2427.2009.02192.x

Mohr C.E. \& Poulson T.L., 1966 - The life of the cave. New York: McGraw-Hill.

Morano E. \& Cardoso P., 2011 - Iberian spider catalogue (v2.0). Available online at: http://www.ennor.org/iberia.

Myers N., Mittermeier R.A., Mittermeier C.G., Fonseca G.A.B. \& Kent J., 2000 - Biodiversity hotspots for conservation priorities. Nature, 403: 853-858. http://dx.doi.org/10.1038/35002501

Northup D.E. \& Lavoie K.H., 2001 - Geomicrobiology of caves: a review. Geomicrobiology Journal, 18: 199222.

http://dx.doi.org/10.1080/01490450152467750

Oromí P., 2004 - Biospeleology in Macaronesia. AMCS Bulletin, 19: 98-104.

Pausas J.G. \& Verdú M., 2010 - The jungle of methods for evaluating phenotypic and phylogenetic structure of communities. BioScience, 60: 614-625. http://dx.doi.org/10.1525/bio.2010.60.8.7 
Petchey O.L., 2004 - On the statistical significance of functional diversity effects. Functional Ecology, 18: 297-303.

http://dx.doi.org/10.1111/j.0269-8463.2004.00852.x

Petchey O.L. \& Gaston K.J., 2002 - Functional diversity (FD), species richness and community composition. Ecology Letters, 5: 402-411. http://dx.doi.org/10.1046/j.1461-0248.2002.00339.x

Petchey O.L. \& Gaston K.J., 2006 - Functional diversity: back to basics and looking forward. Ecology Letters, 9: 741-758.

http://dx.doi.org/10.1111/j.1461-0248.2006.00924.x

Pipan T., López H., Oromí P., Polak S. \& Culver D.C., 2011 - Temperature variation and the presence of troglobionts in terrestrial shallow subterranean habitats. Journal of Natural History, 45: 253-273. http://dx.doi.org/10.1080/00222933.2010.523797

Platnick N.I., 2011 - The world spider catalog, version 12.0. American Museum of Natural History, online at http://research.amnh.org/iz/spiders / catalog. http://dx.doi.org/10.5531/db.iz.0001

Podani J. \& Schmera D., 2006 - On dendrogram-based measures of functional diversity. Oikos, 115: 179185. http://dx.doi.org/10.1111/j.2006.0030-1299.15048.x

Rabinowitz D., 1981 - Seven forms of rarity. In: Synge H. (Ed.) - Aspects of rare plant conservation. New York: Wiley: 205-217.

Ribera C., 1977 - Contribucion al conocimiento de la fauna cavernicola de Cataluna. Familia Agelenidae. Comunicaciones del VI Simposium de Espeleologia: 153-155.

Ribera C., 1978 - Contribucion a la conaissance de la faune cavernicole du Nordest de l'Espagne: le genre Meta. Symposia of the Zoological Society of London, 42: 353-358.

Ribera C., 1979a - Distribucion des Nesticidae cavernicoles de la Peninsule Iberique. Revue Arachnologique, 2: 291-300.

Ribera C., 1979b - Le genre Porrhoma dans les cavites de la Peninsule Iberique. Compte-Rendus V Colloque d'Arachnologie d'Expression Française: 213-216.

Ribera C., 2004 - Dysdera valentina (Araneae, Dysderidae), una nueva especie de la provincia de Valencia, con algunas adiciones a la fauna cavernicola Iberica. Revista Iberica de Aracnologia, 9: 211-215.

Ribera C., De Mas E. \& Barranco P., 2003 - Araneidos cavernicolas de la provincia de Almeria (I) y descripción de cuatro especies nuevas. Revista Iberica de Aracnologia, 7: 3-17.

Rodrigues A.S.L. \& Gaston K.J., 2002 - Maximising phylogenetic diversity in the selection of networks of conservation areas. Biological Conservation, 105: 103-111.

http://dx.doi.org/10.1016/S0006-3207(01)00208-7

Schneider K. \& Culver D.C., 2004 - Estimating subterranean species richness using intensive sampling and rarefaction curves in a high density cave region in West Virginia. Journal of Cave and Karst Studies, 66: 39-45.
Sharratt N.J., Picker M.D. \& Samways M.J., 2000 The invertebrate fauna of the sandstone caves of the Cape Peninsula (South Africa): patterns of endemism and conservation priorities. Biodiversity and Conservation, 9: 107-143.

http://dx.doi.org/10.1023/A: 1008968518058

Slaney D.P. \& Weinstein P., 1997 - Conservation of cave fauna: more than just bats. Memoirs Museum Victoria, 56: 591-596.

Sket B., 1999 - The nature of biodiversity in hypogean waters and how it is endangered. Biodiversity and Conservation, 8: 1319-1338. http://dx.doi.org/10.1023/A:1008916601121

Sket B., 2008 - Can we agree on an ecological classification of subterranean animals? Journal of Natural History, 42: 1549-1563. http://dx.doi.org/10.1080/00222930801995762

Tilman D., Knops J., Wedin D., Reich P., Ritchie M. \& Siemann E., 1997 - The influence of functional diversity and composition on ecosystem processes. Science, 277: 1300-1302.

http://dx.doi.org/10.1126/science.277.5330.1300

Tuomisto H., 2010a - A diversity of beta diversities: straightening up a concept gone awry. Part 1. Defining beta diversity as a function of alpha and gamma diversity. Ecography, 33: 2-22.

http://dx.doi.org/10.1111/j.1600-0587.2009.05880.x

Tuomisto H., 2010b - A diversity of beta diversities: straightening up a concept gone awry. Part 2. Quantifying beta diversity and related phenomena. Ecography, 33: 23-45.

http://dx.doi.org/10.1111/j.1600-0587.2009.06148.x

Warwick R.M. \& Clarke K.R, 1995 - New "biodiversity" measures reveal a decrease in taxonomic distinctness with increasing stress. Marine Ecology Progress Series, 129: 301-305. http:/ / dx.doi.org/10.3354/meps 129301

Warwick R.M. \& Clarke K.R, 1998 - Taxonomic distinctness and environmental assessment. Journal of Applied Ecology, 35: 532-543. http://dx.doi.org/10.1046/j.1365-2664.1998.3540532.x

Whittaker R.H., 1960 - Vegetation of the Siskiyou mountains, Oregon and California. Ecological Monographs, 30: 279-338. http:/ / dx.doi.org/10.2307/1943563

Whittaker R.H., 1972 - Evolution and measurement of species diversity. Taxon, 21: 213-251. http://dx.doi.org/10.2307/1218190

Whittaker R.J. \& Fernández-Palacios J.M., 2007 - Island Biogeography: ecology, evolution, and conservation. Oxford: Oxford University Press.

Whittaker R.J., Jones S.H. \& Partomihardjo T., 1997 - The re-building of an isolated rain forest assemblage: how disharmonic is the flora of Krakatau? Biodiversity and Conservation, 6: 1671-1696. http://dx.doi.org/10.1023/A: 1018335007666

Williams P.H., 1996 - Mapping variations in the strength and breadth of biogeographic transition zones using species turnover. Proceedings of the Royal Society: Biological Sciences, 263: 579-588. http://dx.doi.org/10.1098/rspb.1996.0087 
Zagmajster M., Culver D.C. \& Sket B., 2008 - Species richness patterns of obligate subterranean beetles (Insecta: Coleoptera) in a global biodiversity hotspot - effect of scale and sampling intensity. Diversity and Distributions, 14: 95-105. http://dx.doi.org/10.1111/j.1472-4642.2007.00423.x
Zagmajster M., Culver D.C., Christman M.C. \& Sket B., 2010 - Evaluating the sampling biasin pattern of subterranean species richness: combining approaches. Biodiversity and Conservation, 19: 3035-3048. http://dx.doi.org/10.1007/s10531-010-9873-2 